$\langle$ 日本農芸化学会賞〉

\title{
赤血球造血因子（エリスロポエチン）の新しい生理作用の 発見と生合成の調節機構に関する研究
}

京都大学大学院農学研究科応用生命科学専攻 佐々木 隆 造

エリスロポエチン (EPO) は未分化な赤血球前駆細 胞に作用し，その分化・增殖を促進する糖蛋白質であ り，赤血球の形成を制御する最む重要な因子である. EPO は腎臓で合成され，血液中を運ばれ造血の場で ある骨䯣に到達し作用する，すなわち，造血系（腎臟

・骨髄)では EPO はエンドクライン (内分泌様式)で 作用するホルモンである.EPO遗伝子は貧血など低 酸素状態になると，転写が活性化され造血が促進され 負血が改善される，EPOは，造血にのみ作用すると信 じられてきたが, 演者は，EPOが局所において今まで 全く予想されなかった新機能をあっことを発見した。 すなわち，EPO は中枢神経系における神経細胞の生 存および子宮組織内の血管新生に重要である(図参 照).ここに, 造血系, 中枢神経系, 子宮血管系におけ るEPO の機能と組織特異的発現の制御に関する研究 成果をまとめる，EPO あるいはその受容体のノック アゥトマウスは, 胎生期の造血低下により胎生 14 日 で死亡し，成体での EPO の機能を観察することはで きなかった，本研究は，EPO受容体の細胞外領域すな わち可溶型受容体 (EPOに結合可能)を使用し，成体 におけるEPOの新機能を発見したことを特色とす る.

1. 造血系に関する研究

（1）単離法，生産法，および定量法

ヒトEPOに対する単クローン抗体を取得し，EPO

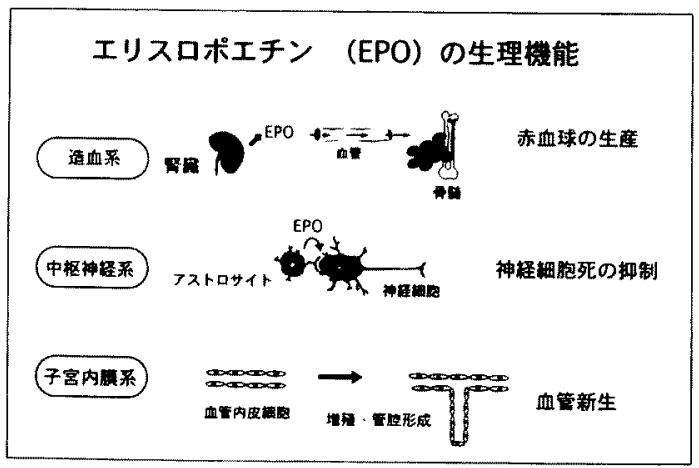

图
の迅速かつ高収率な単離法を作成し, 組換え型七ト EPOの生産系を開発した。 また, 単クローン抗体を利 用した超高感度の迅速定量法を確立し，EPO 生産細 胞の同定や病態の診断などに利用した。

\section{(2) 糖鎖の構造と機能}

$\mathrm{EPO}$ は 165 個のアミ/酸からなる蛋白質であり，3 本の $N$ 結合型糖鎖を持つ. 組換え型および天然型 $\mathrm{EPO}$ の糖鎖の構造を決定した，さらに，部位指定㔖然 変異法により糖鎖結合部位を欠失した EPO を生産し 精鎖の生理機能を解明した。すなおち， $N$ 結合型糖鎖 は EPO の血流中での安定化に必須であり, in vivo 活 性の発現に必要である。ただし, 糖鎖は in vitro の活 性発現には必要でない，また，糖鎖は生産細胞から分 泌される過程に必要である，さらに，細胞外への EPO 分泌には方向性（極性分泌）があり，この極性分泌に 糖鎖が直接関与すること発見し，糖蛋白質の糖鎖に関 する新しい機能を示した。

\section{(3) 堅㖶における EPO 生座の制御}

低蛋白質の摄取は赤血球量の低下による賓血を招 く。これまで血液 EPO の正確な定量法は困難であっ たが, 確立した高感度定量法を駆使し, 低蛋白質摄取 による赤血球量の低下は EPO 生産量の低下によるこ とを初めて証明した。低蛋白質摄取により造血組織中 の EPO 標的細胞の含量は顕著に低下し，この低下は $\mathrm{EPO}$ の投与により完全に防止できる.すなおち, EPO は標的細胞の生存因子として標的細胞のプールサイズ の維持に重要である. EPOが存在しない場合には, 標 的細胞はアポトーシスの過程をたどり死烕する.さら に，ビタミン A が EPO 合成に必要であること， EPO 遺伝子にレチノイン酸応答配列が存在することを指摘 した.

2. 中枢神経系に関する研究

(1) 中枢神経系における EPO 受容体の発現と EPO 生合成

神経細胞に EPO 受容体が発現していること, 神経 グリア細胞の一種であるアストロサイトが EPO を生 産していることを発見した，中枢神経系は血液脳関門 
により血液とは隔離されており，血液中の EPO は中 枢神経系には作用することはない，すなわ年 $\mathrm{EPO}$ に 関して, 内分泌椂式で作用する造血系とは全く独立 し，傍分泌（パラクライン）様式で作用するシステム が中枢神経系に存在することになる。神経系における $\mathrm{EPO}$ 遺伝子の発現は, 腎臟と同じく低酸素により誘 導される.

\section{（2）中枢神経系における EPO の機能}

神経系の EPO 生産が低酸素により誘導される現象 は, $\mathrm{EPO}$ が虚血（血流停止）による神経細胞死亡関係 することを示唆する，事実，脳内虚血処理を与えた動 物の脳室内に EPO を投与すると海馬の神経細胞死が 抑制され，学習・記憶力の低下を防止する。また， EPO の可溶型受容体（EPO と結合可能）を投与する 之, 脳内 $\mathrm{EPO}$ を捕捉し, 神経細胞死をひき起こす。す なわち, $\mathrm{EPO}$ が神経細胞を保護する機能をもつこと を in vivo 実験で示した，虚血による神経細胞死は興 鹤性神経伝達物質であるグルタミン酸 (Glu) の毒性に よるとされている. EPO は Glu による培養神経細胞 死を完全に抑制する。

\section{3. 子宮内膜系に関する研究}

\section{（1）子宮内膜血管新生における EPO の機能}

$\mathrm{EPO}$ が培養血管内皮細胞に作用することが報告さ れているが，この現象の生理的意義については証明さ れていない，子宮内膜采は，健常な成体て唯一の血管 新生が激しく起こる部位である。すすなわち, 性周期に 応じて, 子宮内膜組織の構築と䈹退が繰り返され, 構 築期に激しい血管新生が行われる。この構築は, 卵巣 ホルモンであるエストロゲンの支配下にある。この点 に着目し，EPOの可溶型受容体を子宮腔内に投与す ると血管新生が著しく阻害されることを発見した。ま た，卵巣摘出した動物の子宮腔内に $\mathrm{EPO}$ を投与する
と血管形成が観察され，EPO は子宮内膜層の血管新 生に必須である。

\section{(2) 子宮内膜系における EPO の生合成}

卵巣摘出した動物の子宮組織を培養し, 培養時に工 ストロゲンを添加する上EPO 遗伝子発現が誘導さ れ，培地に EPO が生産される。腎蔵および神経系で の $\mathrm{EPO}$ 生産はエストロゲンは効果がなく，また子宮 組織における EPO 生産は低酸素によりほ上んど誘導 されない，すなわち，子宮内膜系の EPO/EPO受容体 システムは, 造血系抢よび神経系とは異なる制御を受 けている。

以上のように，EPO 生合成は組織により異なる制 御を受けている。八イポキシア (低酸素)による $\mathrm{EPO}$ 遗伝子発現誘導の分子機構は精力的に研究が行われて いるが，ビタミンA㧍よびエストロゲンの作用の分 子機構については不明である。また, EPOの神経系㧍 よび子宮血管系における作用の分子機構についても， これからの研究が必要である。

本研究は, 京都大学農学部食品工学科食品化学講座 および京都大学大学院農学研究科応用生命科学専攻生 体情報応答学分野（平成 9 年 4 月改組）において行わ れた。ご指導を賜わりました千葉英雄京都大学名誉教 授をはじめ，研究に協力いただきました卒業生㧍よび 研究室の皆様に感謝申し上げます。また, 本研究は, 雪印乳業株式会社生物科学研究所の方々, 安田佳子氏 (近畿大学), 阪中雅弘氏 (受媛大学), 田平武氏 (国立 精神・神経センター神経研究所), 加藤茂明氏 (東京大 学), 今川重彦氏 (自治医科大学), 北川泰雄氏 (名古 屋大学), 成田宏史氏 (京都女子大学), 高畑京也氏 (岡 山大学), 白井義人氏 (九州工業大学) の協力に上り行 われたものであり、ここに深甚なる謝意を表します。 